Saudi Journal of Economics and Finance

Abbreviated Key Title: Saudi J Econ Fin ISSN 2523-9414 (Print) |ISSN 2523-6563 (Online) Scholars Middle East Publishers, Dubai, United Arab Emirates Journal homepage: http://saudijournals.com/sjef/

\title{
Analysis Planning Village Owned Enterprises in the Village of Batu Raya I Timang District North Barito
}

\author{
Noormalia Ulfah", Budi Suryadi, Jamaluddin \\ Master Program of Government Science, Lambung Mangkurat University, Banjarmasin, Indonesia
}

\author{
DOI: $10.36348 /$ sjef.2019.v03i11.011 $\quad$ | Received: 09.11.2019| Accepted: 16.11.2019| Published: 19.11 .2019 \\ *Corresponding author: Noormalia Ulfah
}

\section{Abstract}

This study aimed to describe the planning analysis village-owned enterprises in the village of Batu Raya I, precisely District of Gunung Timang North Barito regency. A qualitative approach was used to describe the problem. Similarly, I conducted three phases of data collection. The informant research; Kades, Sekdes, Chairman of the BPD, Chairman BUMDes, and residents of the village of Batu Raya I. The data analysis interactive model of Miles and Huberman have to get the data saturation. Based on the results of research and discussion, we conclude that in the planning of the village government in Batu Raya I BUMDes aspects of policies, procedures, programs, budgets, and progress have shown good results. Factors inhibiting government planning in the village of Batu Raya I BUMDes, which include the lack of public participation inequity through BUMDes Batu Raya I, so capital BUMDes Batu Raya I purely from APBDes. While supporting factors such as support for existing resources natural resources, human and financial resources, and the support of the central government, provincial, district, and village and also the cooperation of a third party. North Barito District Government needs to undertake policy formulation in the form of regional regulation as an effort to strengthen the capacity and protect BUMDes of competition. Besides, it should increase the capacity of the village government and BUMDes managers related to planning (planning skills).

Keywords: Analysis, Planning, and the village government.

Copyright @ 2019: This is an open-access article distributed under the terms of the Creative Commons Attribution license which permits unrestricted use, distribution, and reproduction in any medium for non-commercial use (NonCommercial, or CC-BY-NC) provided the original author and source are credited.

\section{PRELIMINARY}

According to Minister Regulation No. 39 the Year 2010, is a business BUMDes village formed/established by the village government in which ownership of capital and management carried out by the village government and community. The purpose of the establishment of BUMDes a government effort to improve the financial capability of the village government in governance and increase incomes through a variety of economic activities of rural communities [1].

BUMDes existence is also strengthened by the Ministerial Regulation No. Village 4 the Year 2015 on the establishment, maintenance and management and the dissolution of the village-owned enterprises. The establishment of these institutions among others is intended to reduce the role of middlemen who often led to increased transaction costs between the prices of products from the manufacturer to the end consumer. Through this agency is expected every manufacturer in the countryside can enjoy the difference in the selling price of products with proper production costs and consumers do not have to bear the expensive purchase price. Assist the needs of public funds is consumptive and productive. Being the main distributor to meet the needs of nine staple (staple food).

Besides, functions grow activities in rural economic actors. BUMDes in the village sustained by monetary institutions (financing units) as units that perform financial transactions such as loans and deposits. If strong and sustained economic institutions adequate policies, economic growth accompanied by a more equitable distribution of assets to the people at large will be able to cope with various economic problems in the countryside. The end goal BUMDes as an instrument of social capital is expected to be the prime mover in bridging efforts to strengthen the rural economy [2].

Capitalization village-owned enterprises can derive from the village government, community savings, help the Government, Provincial Government and District / City, loans or equity participation of others or cooperate based on mutual benefit villageowned enterprises may apply for loans, which can be done after approval BPD. Not easy in implementation 
in the field or practice, all of which would need attention and the role and participation of all parties, through various efforts that pass through Education, Human Resources and nature is, which of course could affect the budget of a region or village.

Building a strong and independent country can be done by forming a well-managed BUMDes, if the potential can be maximized village, automatically will be influential in improving standards of living [3]. Particularly in North Barito regency in the sub-district of Mount Cuddle, in each village does own BUMDes. However, of the total 16 villages, only 3 villages are active in conducting BUMDes. One is BUMDes in the village of Stone Kingdom I. BUMDes in another village merely standing but no BUMDes active in business activities. Planning and establishment in the village of Batu highway BUMDes I are on the initiative of the village administration, village government could establish an economic institution which then mandated the Rural Medium Term Development Plan (RPJMDes).

Rural Medium Term Development Plan (RPJMDes) Batu Raya I 2016 one village government program in economics is to establish BUMDes that local excellence and encourage equitable development investment rate. Moving on from the program, the village government to follow up with BUMDes consulted to establish. and gave the name as the name BUMDes Mitra Karya Raya Batu BUMDes in the management ranks BUMDes first set and saw the potential in the village of Stone Kingdom I. BUMDes in the village of Stone Raya I stood up and active in BUMDes. In the aspect of planning is ideally targeted and sustainable. So BUMDes add business units that can be felt directly by the people in the village.

\section{RESEARCH METHODS}

This study used a qualitative approach and descriptive type. Through a qualitative approach, this study aimed to describe the real situation in detail and real-time and tailored to the issues and objectives of the research [4]. It is used because the phenomenon under study requires in-depth description and analysis which is expected in the study can be found answers and can reveal the actual events on the ground. This type of research in this study was descriptive. Researchers presented the results of research in the description or descriptions that describe the relevant events in the Village Government Planning village-owned enterprises in the village of Stone Mountain Cuddle Kingdom I Sub North Barito regency. Data were extracted include two types of data; 1) The primary data which includes the extracted data to the informant interviews, 2) secondary data extracted includes documents such as statements.

The data collection technique used involves three steps, namely; 1) Interview in the form of free questions with informants involved either directly or indirectly related to the Desa government planning on village-owned enterprises in the village of Stone Mountain Cuddle Kingdom I Sub North Barito regency. 2) Observations regarding the object of research, and 3) Documentation is collecting relevant data and already assembled and managed by the BUMDes in Barito Utara. Interactive data analysis and continues over at every stage of research to completion and extracting data to obtain the most precise information [5].

First, data reduction by choosing the subject matter considered important. Second, the presentation of data in table form or narrative text to form the configuration of relationships and interconnections of the phenomenon. Third, the conclusion that in this part of researchers searching for the red thread on the data that has been presented and interpreted so that eventually could lead to the conclusion in the form of categories of data. Concerning the validity of qualitative data is intended to test the veracity and honesty of a description, inference, explanation, interpretation, and contents of the report as a whole. In a study to test the validity of the information received is done by triangulation. Two triangulation techniques used are; triangulation methods and sources [6].

\section{RESULTS AND DISCUSSION}

Planning is the selecting and connecting facts, using assumptions about the future in making visualization and formulation of the proposed activity and is necessary to achieve the desired results. Planning is an attempt to choose the action of various alternatives that may be available that include strategies, policies, programs, projects and procedures to achieve organizational goals. The planning function also includes the determination of the appropriate tools to reach the goals [7].

Planning set goals are achieved, the actions that should be implemented, the appropriate form of organization to achieve it and the people responsible for the activities carried out. Planning involves decisions about what to do, how to do it, when to do it and who did. The planning function is the decision-making process concerning the results to be achieved, the use of resources, and the establishment of a communication system that allows the reporting and control of actual results and comparison of these results [8].

The planning function is a function of the underlying and preceding others. Functions plans can be viewed as a process of targeting and selection to achieve those goals. Without the leadership of the government, planning can not figure out how to organize human resources and natural resources effectively. They probably do not even have a clear idea of what they need to organize. The government's plan means of determining the decision making process regarding government activities carried out for a certain 
period in the future be directed to the purpose set together [9].

Viewed as election planning and connecting facts, using assumptions about the future and make the formulation of the proposed activity and is necessary to achieve the desired result [10]. Stone BUMDesa related to planning Raya I where planning therein is a regular preparation of any effort to realize the objectives of BUMDes Batu Raya I was alone, so the elements that exist in the planning BUMDes Batu Raya I consists of:

\section{Policy}

Related policies BUMDes Batu Raya I met the elements of the policy that supports the planning BUMDesBatu Raya I own. The policy is Permendesa No. 4 of 2015 on the Establishment, Management and Administration, and Dissolution, village-owned enterprises. Planning for the existence ofBUMDes Batu Raya I alone in its policies should also be accompanied by efforts to strengthen the capacity and supported by regional policies, which also facilitated and protect businesses from the threat of competition villagers large investors through the local legislation for BUMDes a new economic institutions that operate in the countryside, they still need a solid foundation to grow and develop.

\section{Procedure}

No policy through the local legislation of the district government, the detailed procedures follow the rules above, which follow Permendesa No. 4 of 2015 on the Establishment, Management and Administration, and Dissolution, village-owned enterprises. The policy platform provides the primary purpose of the organizationBUMDes itself, which is also the basis for the BUMDesBatu Raya I related to its existence. Steps taken by the village government is right, because if the society no related initiativesBUMDes, then BUMDes The village was initiated by the government, as happened in the village of Stone Kingdom I. There are three (3) steps to be taken by the village of Batu Raya I in establishments BUMDes, that is:

\section{DISCUSSION}

Institutions at the village level, there must be discussions that involve all elements that exist in the village, such as village heads, community leaders, and others. Inside this deliberation, we must obtain a chance that the village would like to have BUMDes, Deliberation should also discuss the business unit, management, sources of capital, and other things to support the running program. But most importantly, in these deliberations, as well as the organizational structure of any business unit that will be developed is already determined. Thus, the already visible direction in whichBUMDes taken.

\section{Organizational settings}

The second step is the organization's Rulemaking BUMDes, This includes the duties and functions of each managerBUMDes, Moreover, at this stage, it is discussed also developed business plans complete with what immediate steps should be executed.

\section{Development}

At this stage, the organizational structure has been created, and each division has understood each task, so, at this stage, the implementation of the activities already carried out. Discussion to technical matters such as determining the third party cooperative, business unit development program that has been agreed, and devise ways of payroll memberBUMDes, It submitted by the head of the village on the results of research regarding the establishment planningBUM VillageBatu Raya I own in accordance with Article 4 Permendesa No. 4 of 2015 which suggested that the village can establish BUMDes. Villages may establish BUMDes with some considerations include:

1) The village government initiatives and / or the village community.

2) Rural economy business potential.

3) Resource nature in the village.

4) Resource humans can manage BUMDes,

5) Equity of the village government in the form of financing and wealth village is submitted to be managed as part of the effort BUMDes,

Step drafting BUMDes followed by planning for the establishment of business units must not be separated from the support of people who believe the village government to plan, establish and selecting business manager through BUMDes although the participation of the community in terms of capital investment is still not there, but the moral support and the shift means selling crops and conventional fertilizer purchases to the BUMDes would provide a symbiotic mutualism form of village government, BUMDesand the society. However, it should be discussed related to this procedure is in the planningBUMDes in the procedure is not described how constituent capacity planning, because it is considered that the existing procedures are clear, without a planner who has a predefined capacity have good planning skills will make planning could have unfavorable [11].

\section{Program}

In planning BUMDesBatu Raya I, the program has been structured well enough where the program directs the organization's main objectives namely the public welfare by improving their economy. However, in setting the program itself is the village government is fully involved in the planningBUMDes Raya Batu I. But for the overall business plan itself was developed by board BUMDesand the results are presented and requested approval to the Village Government. However, there is also the direction of the District Government through Plan Programs/Economic Development Rural Based Needs to Support Competitive Products of the village of Government North Barito district with programs that support and the 
corresponding potential of the village and the condition of the village as a study conducted by the Government of North Barito regency.

However, should the program planning requirement to have an effective target to be achieved by the SMART concept which stands for specific (specific), measurable (measurable), achievable (achievable), realistic (realistic), and time-based (based on time), Specifically BUMDes Batu Raya I want to give a clear contribution and help the community as well as profitable villages that are a win-win solution, giving things to help people through the provision of subsidized fertilizers more affordable, provision of means of production of farmers easier and purchase production farmer and community gardens to provide a faster income to the community, and also benefit the villagers by providing positive income.

Planning is done already measured well, so grandiose and could be developed well, although quantitatively not maximized. Suppose the procurement planning fertilizer subsidies gradually, first to the needs of people Desa Batu Raya I own, which later evolved to provide the needs of neighboring villages according to the farming group number. Plans are carried out also can be accomplished by a specified time and capacity, as well as the purchasing capacity of agricultural products was offset by selling a capacity of BUMDes Batu Raya I own.

Quantitatively there are no exact figures in the planning regarding the procurement of fertilizers following the needs and the level of marketing targeted figures, there are only qualitatively planning by looking at the number of existing farmer groups. Regardless of the plan is realistic, as if nothing could be done and not profitable it will be to evaluate the planning and execution in order to reorder more realistic plan as an example when running a business supplier of cocoa for Java is done to re-review because it does not do a cooperation agreement and it is not clear cooperation it is considered less realistic business carried on if there is no clarity related to the supply of which is ultimately conducted the review with a more mature concept.

Time limits would provide a clear target for BUMDes in business planning, for example in the case of fertilizer supplier, where the timeline should they want and think carefully because it is associated with plantation and farming community that certainly is no time limit when the process of planting and harvesting so that the BUMDes can also plan a time base for the procurement process and ensure availability of fertilizers to the public.

\section{Budgets}

In the budget, planning BUMDes Batu Raya I own is quite good with a pretty good capital structure that is of APBDesa Batu Raya I, which in 2018 included Rp. 200 Million. Assessed in this case is considered healthy continuity with the flow returns that contribute positively to Pages were 2017 of BUMDes Rp. 9 million, 2018PEDesnya from BUMDesRp. 50 million. Of course it supports all of the advanced planning in the future and it has the added value of the assessment planning process conducted by the village authorities and BUMDes Batu Raya I. But keep in mind related to the budget where the budget planning should be more leverage BUMDes themselves with party funds The third of the community as a form of public participation, but during the budget structure still relies on funds from APBDes and less participation from the community, it will create the impression that as BUMDes are the property of the village, does not belong to the community.

\section{Progress}

Progress of planning BUMDesBatu Raya I own run shows no significant matters that lead to the development of enterprises by emphasizing also the nature of prudent planning. Progress can be seen from the achievement of several goals of existence itself BUMDes namely:

a. Improved rural economy, where BUMDes Batu Raya I run the business of supplying subsidized fertilizers are cheaper and accommodate the community plantation which of course gives certainty on unsold agricultural and plantation community members very helpful in the economy village.

b. Asset optimization village to be beneficial for the welfare of the village, it can be seen from the village asset investments in the form of investment from the Village Fund BUMDes Batu Raya I are increasing every year due to the existence of BUMDes Raya Batu useful and contribute to the welfare of the village.

c. Increased community efforts in the management of rural economic potential, economic potential of agriculture and farming village of Batu Raya I, which is the main business of rural communities greatly assisted by the BUMDes Batu Raya I and their efforts also increased due to storage of agricultural and plantation where farmers' crops and residents purchased BUMDes to be channeled back impact velocity of money people have become faster and help the existence of the business community itself.

d. Develop a plan of cooperation between rural businesses and / or with a third party, which in the initial plan of cooperation with a third party that is Pupuk Kaltim, intended for BUMDes Batu Raya I can provide subsidized fertilizer to villagers of Batu Raya I own which is then developed with the cooperation of the neighboring villages such as the village of Batu Raya II and Village Stick in the provision of subsidized fertilizer through BUMDes Raya Batu I. Then in 2019 is planning cooperation with Pertamina is being carried out exploration in order to provide subsidized LPG to 
villagers of Batu Raya I so that the public can be given easier access to energy.

e. Creating opportunities and market networks that support public service needs of citizens, BUM Village Batu Raya I continue to create better opportunities for agriculture and plantations as well as market network that continually made the assessment as open cooperation with third parties for the sale of the estate of the village of Batu Raya I like cocoa to open the market network better, and still provide good public services to accommodate the crop and fertilizer distribution to the public.

f. Job opportunities, where BUMDes Batu Raya I and effort open to the wider business field, in addition to the public to be more motivated by the certainty of income from the plantation and agriculture, the field is open freight business as a form of support of the purchase of crop establishment and distribution of fertilizer.

g. Improve social welfare through the improvement of public services, economic growth and distribution Village, existence BUMDesBatu Raya I, from the beginning planned to be able to contribute to society as a form of social businesses that can provide public services and support economic growth and distribution of the village, then business related to the plantation and agricultural support rural economy as potentials. The availability of agricultural inputs better and certainty bought agricultural production and farm and fertilizer support available, provide the logic to the welfare of society through a smaller venture capital with a more certain income.

h. Increase people's income and revenue village Village, where BUMDes Batu Raya I planned it well, whether it is related to human resources who understand what you do and be able to open communication in cooperation with third parties as well as support from the government, business form were also selected for the welfare of the community's economy a lot, of course, provide a better income to the community and contribute to the positive revenue and growing village better.

Achievement of the objectives of BUMDes alone in the village of Stone Raya I on an ongoing basis by the manager BUM VillageBatu Raya I create a business plan that is prudent and thorough consideration. The achievement shows a good direction in the planning process of BUMDes funds. This can be seen in which the business plan that emerged from the BUMDes and looks to the proposals from the public as a form of participatory development, which with careful consideration by the village government decided to be implemented or not the proposed plan. Examples of savings and loan business proposal, which is not carried out with a variety of business risk considerations [12]. But take a gas cylinder procurement plan for the community because it is more important in the public welfare-related businesses.

\section{CONCLUSION}

Planning is important in the formation of business village-owned enterprises (BUMDes). Are planning goal setting, procedures and programs established businesses but in reality, there are few people even administrators do not comply with the existing procedures of the various programs and even set up only one is realized. Organizing must be outside the organizational structure of the village government, since the establishment of village-owned enterprises (BUMDes). In the village government planning on BUMDes Batu Raya I of the aspects of policies, procedures, programs, budgets, and progress have shown good results. Factors inhibiting government planning in the village of Batu BUMDes Raya I, which include the lack of public participation inequity through BUMDes Batu Raya I, so that capital BUMDes Batu Raya I purely from APBDes. While supporting factors such as support for existing resources both natural resources, human and financial resources, and the support of the central government, provincial, district, and village and also the cooperation of a third party as a supporter or manufacturer distributor (supplier) for BUMDes.

\section{REFERENCES}

1. Ambar, T. S. (2004). Kemitraan dan Model-Model Pemberdayaan. Yogyakarta: Penerbit Gava Media.

2. Dharma, S. S. (2007). Manajemen Pemerintahan Indonesia. Jakarta: Djambatan.

3. Friedman, J. (1992). Empowerment: The Politics of Alternative Development. Cambridge, Massachusetts: Blackwell Publishers.

4. Creswell, J. W. (2010). Research design: pendekatan kualitatif, kuantitatif, dan mixed. Yogyakarta: PT Pustaka Pelajar.

5. Ibrahim. (2015). Metode Penelitian Kualitatif. Bandung: Alfabeta.

6. Moleong, L. J. (2004). Metodologi Penelitian Kualitatif. Bandung: Remaja. Rosdakarya.

7. Hall, P. (1992). Urban and Regional Planning. London: Routledge.

8. Koso, J., Ogotan, M., \& Mambo, R. (2018). Manajemen Pengelolaan Badan Usaha Milik Desa (Studi Di Desa Watulaney Amian Kecamatan Lembean Timur Kabupaten Minahasa). Jurnal Administrasi Publik.

9. Siagian, S. P. (1996). Manajemen Sumber Daya Manusia. Jakarta: Bumi Aksara.

10. Tjokroamidjojo, B. (1995). Materi Pokok Administrasi Pembangunan. Jakarta: Karunia.

11. Oval Hanif. (2009). Strategic Planning. Jakarta: PT. Pustaka LP3ES.

12. Supriyatno, B. (2009). Manajemen Pemerintahan. Tangerang: CV. Media Brilian. 